\title{
Self-compatible and -incompatible Reactions in Asiatic Hybrid Lilium X 'Enchantment': Influence of Pistil Age on Seed Set
}

\author{
Yoshiji Niimi, Tong-Hua Li and Katsuhito Matsuo \\ Faculty of Agriculture, Niigata University, Ikarashi 2-8050, Niigata 950-21
}

\begin{abstract}
Summary
Cross-pollination ( $L$. hybrid 'Enchantment' $\times L$. maculatum Thunb.) was made before or after anthesis. The receptivity of pistils was observed from 6 days before anthesis (day $-6)$ to 6 days after flowering (day +6 ). On crossing made on day 0 , the number of mature seeds was 185 per capsule, whereas those on day +2 yielded 236 seeds per capsule. Flowers self-pollinated on day 0 yielded no seeds, and the ratio of pollen-tube length / style-length in the pistil was 0.85 . Numerous abnormal pollen tubes with swollen or deformed bulbous tips with delayed generative nuclear division were observed compared with flowers selfed on day +3 . Self-pollinated flowers on day $-3,-2,-1$. $+1,+2,+4$, and +6 developed capsules. Capsules from day +6 flowers produced 46 mature seeds, whereas the others yielded only 13 to 27 seeds per capsule. These find. ings show that $L$.X 'Enchantment' is a relatively weak self-incompatible cultivar. When seeds resulting from flowers self- or cross-pollinated at different stages were planted, differences in germination time and final germination percentage were observed. Of the cross-pollinated mature seeds made on day $0,75 \%$ germinated; of the self-pollinated seeds made on day $+2,72 \%$ germinated, whereas those made on day +6 , only $44 \%$ germinated.
\end{abstract}

\section{Introduction}

Since J. de Graaff (1947) bred Asiatic hybrid Lilium X 'Enchantment'(Shimizu, 1971), the hybrid has been cultivated as a popular garden plant, primarily because they bear several large, nasturtium-red, upright chalice-shaped flowers. The hybrid has also been used as a parent in the breeding of Asiatic hybrid lilies (Shimizu, 1971) because it bears bulbils which simplify propagation of Lilium sp. and has a moderate resistance to Fusarium, a disease which infects the bulbs and roots (Straathof, et al. 1993). These characteristics are advantageous to lily breeders; the lily is heterozygous and breeders are striving to a homozygous line with desirable traits through selfpollination. Unfortunately, $L . \mathrm{X}$ 'Enchantment' produces no mature viable seeds by self-pollination at anthesis (Cheng and Mattson 1972; van Tuyl et al., 1982; Li and Niimi, 1995). By cutstyle pollination (Li and Niimi, 1995) and cultivat-

Received; January 11, 1996. Accepted; April 22, 1996. ing mother plants in a greenhouse at $26{ }^{\circ} \mathrm{C}$ (van Tuyl et al., 1982) several mature seeds can be obtained in this lily. This study was made to determine the most effective pollination time in obtaining as many viable seeds as possible by selfand cross-pollination in this variety. Thus, pollination was made at different stages of flowering to investigate pollen germination on the stigma, tube growth in the style, and time of sperm cell division in pollen tubes.

\section{Materials and Methods}

Bulbs of Asiatic hybrid $L$. X 'Enchantment' and L. maculatum were planted in clay pots in the fall and allowed to overwinter. After the bulbs sprouted, the pots were transferred to a glasshouse, where the night/day temperatures, $10 \sim 20$ ${ }^{\circ} \mathrm{C} / 15 \sim 25{ }^{\circ} \mathrm{C}$, respectively, fluctuated depending on the weather during pollination.

Experiment 1. Self- and Cross-pollination at different stages of pistils

Anthers in flower buds of the $L . X$ 'Enchant- 
ment' were removed before pollination. The pistils were hand-self- or cross-pollinated ( $L$. X 'Enchantment' $\times$ L. maculatum Thunb.) with freshly collected pollen.

Self- and cross-pollination were made at several stages from 7 days before (day -7 ) to 8 days after flowering (day +8 ). The stages of pistils pollinated before anthesis were then determined based on day 0 . For each stage, 3 to 11 flowers were crossed (Table 1) or 4 to 23 flowers were self-pollinated (Table 2) on different plants. Enlarged capsules were harvested 10 weeks after pollination, and the number of mature and empty seeds was identified by the following method: seeds were spread on a transparent glass, and fully developed seeds with an embryo and endosperm were discerned from empty seeds through the transmitted light.

Germination tests of mature seeds were made as follows: 5 seeds were sown in soil (vermiculite and sand $=1: 1 \mathrm{v} / \mathrm{v})$ in a $10.5 \mathrm{~cm} \times 10.5 \mathrm{~cm}$ plastic pot; and 5 pots were used for each treatment. The pots were kept in a growth chamber at $23 / 15^{\circ} \mathrm{C}$ (day/night) under a 16 -hr photoperiod. The frequency of seed germination was recorded every 5 days for 40 days.

Experiment 2. Observations of pollen germination on stigma, pollen-tube growth, and spermcell division in pistils self-pollinated on day $O$ and day +3

\section{1) Pollen germination on stigma}

Three to 9 flowers self-pollinated on day 0 and day +3 were collected 1,6 , and $24 \mathrm{hr}$ after pollination. Stigma with style tissue, about $1 \mathrm{~cm}$ long. were fixed in a modified Karnovsky's solution (Takeoka and Wada, 1985) at $4{ }^{\circ} \mathrm{C}$ for $12 \mathrm{hr}$. Af. ter rinsing the specimen in phosphate buffer solution ( $\mathrm{pH} 7.2$ ), dehydrating in a graded ethanol and 3-methylbutyl acetate, and critical-point drying with $\mathrm{CO}_{2}$ in an ABT critical point dryer $\mathrm{CP}-5 \mathrm{~A}$, they were coated with gold and observed in a Model ABT-55 scanning electron microscopy (Akashi beam technology Co.) at $15 \mathrm{kV}$.

2) Pollen-tube growth and sperm-cell division in selfpollinated styles

Three to 9 flowers were collected $12,24,32$, $48,72,96,120$, and $144 \mathrm{hr}$ after pollination.
Styles with stigmatic tissue attached were dissected from flowers and fixed in FAA (ethyl alcohol $70 \%$ solution : formaldehyde $37 \%$ solution : acetic acid $99.7 \%$ solution $=90: 5: 5 \mathrm{v} / \mathrm{v}$ ) and stored at room temperature until microscopically examined. The entire length of fixed styles from the top of the stigmatic tissue to the base of a style ranged from 40 to $51 \mathrm{~mm}$; the average style length was about $45 \mathrm{~mm}$.

The fixed styles were washed in tap water for 1 $\mathrm{hr}$, followed by immersion for about $40 \mathrm{~min}$ in a 1 $\mathrm{N}$ solution of $\mathrm{NaOH}$ at $60^{\circ} \mathrm{C}$ and washed with tap water. To observe the growth of pollen tubes and their forms with special reference to their tips, the hollow styles were dissected using methods described in a previous paper (Niimi, 1991): (1) a sharp razor blade inserted into the style at the base of stigma and incised circularly; (2) the sty lar tissue was longitudinally cut through from the top to the base; and (3) the bundles of pollen tubes including those attached to the surface layer of the stylar canal were removed from the stylar tissue by picking up the stigma with a pair of forceps. The bundles, stained by methods described below, were observed under fluorescence microscopy.

(1) Determination of pollen-tube length and frequency of deformed pollen tubes.

The softened styles were stained for $12 \mathrm{hr}$ in aniline blue solution (Kho and Baër, 1968). The pollen tubes were straightened as much as possible with the aid of a streaming $45 \%$ glycerin $(\mathrm{v} / \mathrm{v})$ solution for fluorescence microscopy (Merck). After mounting the bundle with a micro-cover glass, both the length of the ten longest pollen tubes and the frequency of abnormal ones with swollen or deformed bulbous tips were determined using a stage micrometer. Three to 7 styles were measured for each treatment. Based on the average length of pollen tubes observed in each style, the ratio of tube length to style-length was calculated.

(2) Observation of sperm-cell division in growing pollen tubes

Three to 7 softened styles per treatment were washed in running water for $48 \mathrm{hr}$ and then rinsed 6 times with distilled water. A bundle of pollen tubes removed from the stylar tissue was transferred onto a slide-glass in humidified petri dishes and stained with a citrate buffer solution 
$\left(\mathrm{pH}\right.$ 4) containing $1 \mathrm{mg} \cdot \mathrm{liter}^{-1}$ DAPI $\quad 4^{\prime} \quad 6$. diamidino-2-phenylindole $\cdot 2 \mathrm{HCl}$ ) and $1 \%$ polyoxyethylene (10) octylphenyl ether. The bundles were kept for $4 \mathrm{hr}$ in an incubator held at $37^{\circ} \mathrm{C}$ and DAPI was dripped onto them hourly.

\section{Results}

\section{(1) Cross-pollination}

\section{1) Seed yield}

Pistils of flowers cross-pollinated at day -6 to day +6 yielded mature seeds (Table 1 ); 6 mature seeds per capsule were obtained from flowers crossed on day -6 ; the yield per capsule increased gradually in the pistils toward day 0 . The total number of mature and empty seeds per capsule was about 300 . The highest number of mature seeds (236 seeds per capsule) was obtained from flowers crossed on day +2 .

\section{2) Seed germination}

The most rapid germination was observed in seeds collected from flowers crossed on day 0 , and the germination rate 40 days after sowing was $75 \%$. Flowers cross-pollinated on day +4 developed more seeds per capsule than did those of day 0 , but the germination rate was only $40 \%$ (Fig. 1).

Table 1. Number of capsules and seed set from flowers of L. X 'Enchantment' cross-pollinated at different floral stages.

\begin{tabular}{ccccc}
\hline \hline $\begin{array}{l}\text { Floral } \\
\text { stages }\end{array}$ & $\begin{array}{l}\text { No. } \\
\text { pollinated } \\
\text { pistils }\end{array}$ & $\begin{array}{c}\text { capsules } \\
(\%)\end{array}$ & $\begin{array}{l}\text { No. maturre } \\
\text { seeds per } \\
\text { capsule }\end{array}$ & $\begin{array}{l}\text { No. empty } \\
\text { seeds per } \\
\text { capsule }\end{array}$ \\
\cline { 4 - 6 } Day -7 & 3 & 0 & 0 & 0 \\
Day -6 & 6 & 67 & $6 \pm 2$ & $134 \pm 31$ \\
Day -5 & 5 & 80 & $21 \pm 8$ & $228 \pm 17$ \\
Day -4 & 7 & 100 & $52 \pm 10$ & $215 \pm 10$ \\
Day -3 & 5 & 100 & $137 \pm 29$ & $151 \pm 22$ \\
Day -2 & 10 & 90 & $175 \pm 10$ & $109 \pm 7$ \\
Day -1 & 11 & 100 & $180 \pm 9$ & $120 \pm 10$ \\
Day 0 & 5 & 100 & $185 \pm 14$ & $137 \pm 12$ \\
Day +1 & 8 & 100 & $229 \pm 11$ & $80 \pm 8$ \\
Day +2 & 5 & 100 & $236 \pm 10$ & $71 \pm 3$ \\
Day +4 & 5 & 100 & $206 \pm 11$ & $102 \pm 10$ \\
Day +6 & 4 & 100 & $149 \pm 8$ & $188 \pm 14$ \\
Day -8 & 8 & 0 & 0 & 0 \\
\hline
\end{tabular}

\pm indicates standard error.

\section{(2) Self-pollination}

\section{1) Seed yield}

Self-pollination was made between day -7 to day +8 (Table 2). Flowers pollinated at day 0 resulted in no capsules. About 48 to $100 \%$ of flowers selfed on day -3 to +6 developed capsules; the maximum number of mature seeds (46 seeds

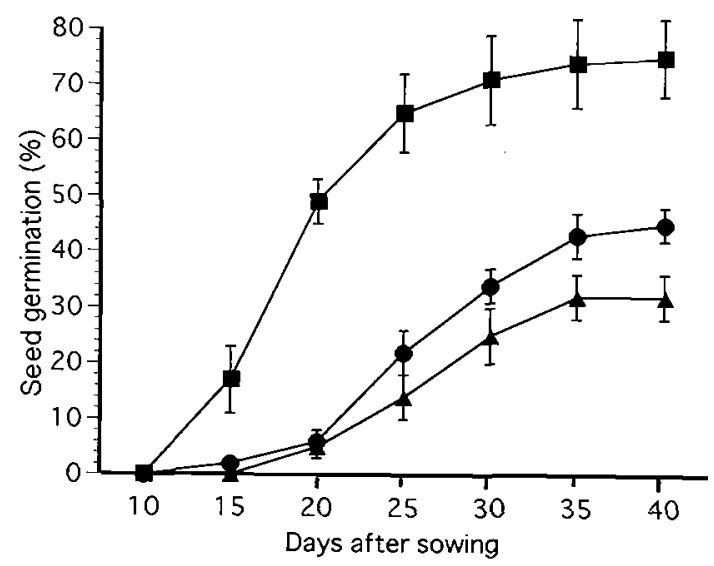

Fig. 1. Cumulative percentage germination of seeds yielded from cross-pollinated flowers of $L . X \cdot E n$ chantment' $\times L$. maculatum on day $0(\square)$, day +4 (O). and day +6 ( $\mathbf{\Delta})$. The vertical bars indicate standard errors.

Table 2. Number of capsules and seed set from flowers of L. X 'Enchantment' self-pollinated at different floral stages.

\begin{tabular}{|c|c|c|c|c|}
\hline $\begin{array}{l}\text { Floral } \\
\text { stages }\end{array}$ & $\begin{array}{l}\text { No. } \\
\text { pollinated } \\
\text { pistils }\end{array}$ & $\begin{array}{c}\text { capsules } \\
(\%)\end{array}$ & $\begin{array}{l}\text { No. maturre } \\
\text { seeds per } \\
\text { capsule }\end{array}$ & $\begin{array}{l}\text { No. empty } \\
\text { seeds per } \\
\text { capsule }\end{array}$ \\
\hline Day -7 & 4 & 0 & 0 & 0 \\
\hline Day -6 & 5 & 0 & 0 & 0 \\
\hline Day - 5 & 5 & 0 & 0 & 0 \\
\hline Day - 4 & 5 & 0 & 0 & 0 \\
\hline Day - 3 & 11 & 55 & $20 \pm 6$ & $145 \pm 22$ \\
\hline Day -2 & 7 & 57 & $27 \pm 7$ & $190 \pm 11$ \\
\hline Day - 1 & 23 & 48 & $13 \pm 9$ & $157 \pm 23$ \\
\hline Day 0 & 5 & 0 & 0 & 0 \\
\hline Day + 1 & 6 & 100 & $15 \pm 3$ & $176 \pm 15$ \\
\hline Day +2 & 5 & 100 & $15: 4$ & $192 \pm 11$ \\
\hline Day +4 & 5 & 100 & $19 \pm 11$ & $225 \pm 11$ \\
\hline Day +6 & 6 & 100 & $46=13$ & $234 \pm 15$ \\
\hline Day +8 & 8 & 0 & 0 & 0 \\
\hline
\end{tabular}

\pm indicates standard error. 
per capsule) was yielded from pistils selfed on day +6 , but the capsules in each treatment had many empty seeds.

\section{2) Seed germination}

About $72 \%$ of the mature seeds obtained from the pistils selfed on day -2 germinated. However, in the pistils selfed on day +6 , only $44 \%$ of the mature seeds germinated (Fig. 2).

(3) Comparison of pollen-tube growth in the styles selfpollinated at day 0 and day +3

\section{1) Pollen germination on stigma}

Almost all stigmatic papillae swelled well on day 0 (Fig. $3 \mathrm{~A}$ ), whereas those of day +3 had wilted (Fig. $3 \mathrm{D}$ ). Pollen germination on the stigma on day 0 began late compared with that which germinated on the stigma on day +3 ; the pollen germination and the tube growth of day 0 flowers were inferior to the latter when observed 6 (Figs. $3 \mathrm{~B}, \mathrm{E}$ ) and $24 \mathrm{hr}$ (Figs. $3 \mathrm{C}, \mathrm{F}$ ) after pollination.

\section{2) Tube growth in the style}

Whether pollinated at anthesis or 3 days later, pollen tubes in the styles showed little difference in length when observed $24 \mathrm{hr}$ after pollination. Thereafter the growth of tubes in the former styles was gradually delayed and almost stopped

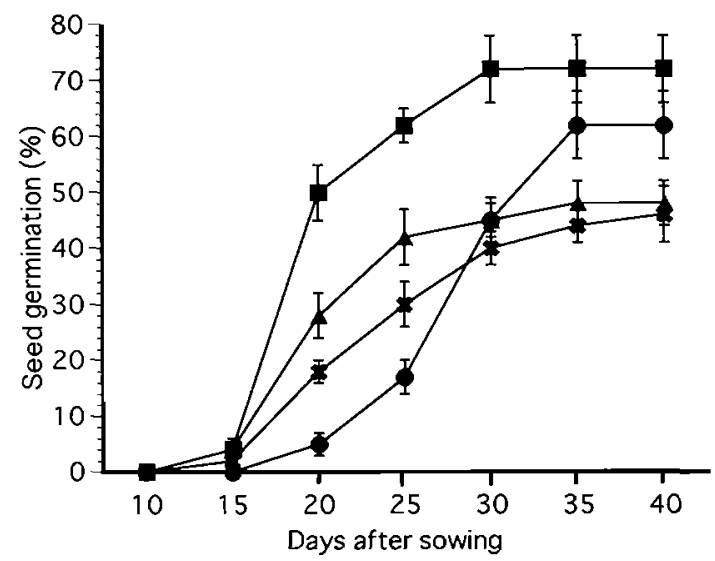

Fig. 2. Cumulative percentage germination of seeds yielded from flowers of $L$. X 'Enchantment' self-pollinated on day $-2(\boldsymbol{\square})$, day +2 ( ) , day $+4(\mathbf{A})$, and day $+6(x)$. The vertical bars indicate standard errors.
$48 \mathrm{hr}$ after pollination (Fig. $4 \mathrm{~A}$ ). Pollen tubes in the styles pollinated on day +3 continuously grew well and reached the base of the styles $48 \mathrm{hr}$ after pollination (Fig. 4 B).

\section{3) Abnormal pollen-tubes}

In the pistils pollinated at anthesis, abnormal tubes with swollen or deformed bulbous tips were frequently observed in the styles at different times after pollination (Fig. 5). The number of abnormal tubes gradually increased with time, eventually reaching $44 \%, 72 \mathrm{hr}$ after pollination, whereas only $15 \%$ of the pollen of day +3 had abnormal pollen tubes (Fig. 6).

\section{4) Division of generative cell}

Generative cell division was first observed 12 hr after pollination (Table 3 ). In pistils pollinated on day +3 , all pollen tubes had two sperm cells and one vegetative cell (' $2 S+V$ ') $36 \mathrm{hr}$ after pollination, whereas in the pistils pollinated at anthesis, the generative cell division was delayed significantly so that only $10 \%$ had ' $2 S+V$ ' $36 \mathrm{hr}$ after pollination; their number increased to $94 \% 144$ hr after pollination.

\section{Discussion}

\section{Receptivity}

Seed yield in plants depends on pollen quality and female receptivity. Times favorable to pollination seem to be easily determined by the number of seeds obtained by pollinating female flowers at different times. Our results show that the female receptivity of the $L$.X 'Enchantment' began at a relatively early stages of pistil development and remained so for about 10 days. Additionally, the production of mature seeds in the flowers of day +1 , day +2 and day +4 was found to be higher than that in the flowers of day 0 (Table 1). This indicates that the pistils of $L$. X 'Enchanment' reach optimum receptivity during a period following anthesis. Cross-pollination in L. longiflorum 'Ace' was effected from day -1 to day +9 (Ascher and Peloquin, 1966).

Leopold and Kriedemann (1975) cited that in some species the receptive condition of the ovary is indicated by the exudation of a viscous material on the stigma. Janson et al. (1994) reported that in L. longiflorum, the exudate covers the entire stig- 


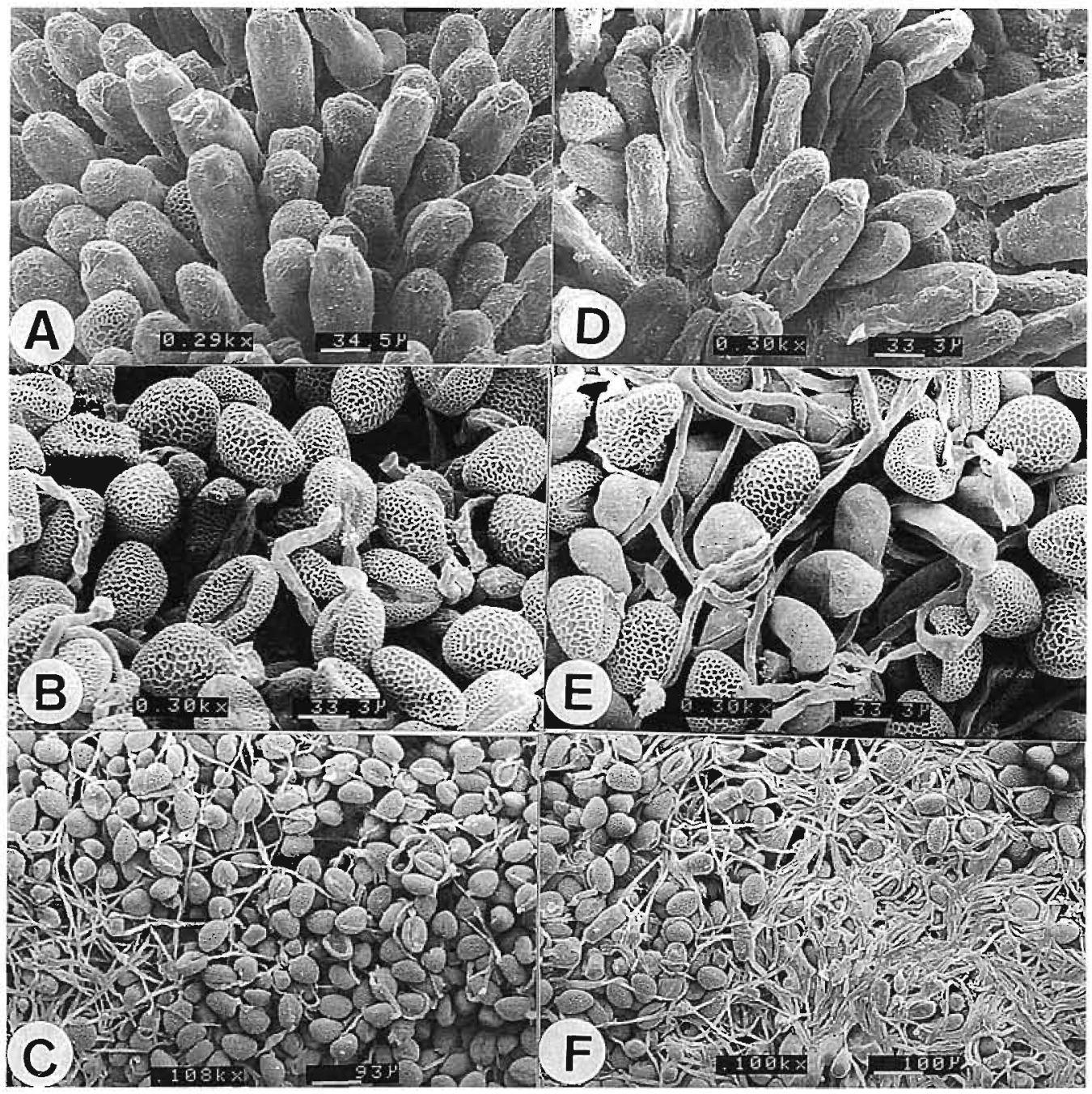

Fig. 3. Scanning electron micrographs of stigmas self-pollinated at the stages of day $0(A, B, C)$ and day +3 (D, $\mathrm{E}, \mathrm{F})$. Observations were made $1 \mathrm{hr}(\mathrm{A}, \mathrm{D}), 6 \mathrm{hr}(\mathrm{B}, \mathrm{E})$ and $24 \mathrm{hr}(\mathrm{C}, \mathrm{F})$ after self-pollination, respectively.

ma on day +2 ; Ichimura and Yamamoto (1992) found that the exudate continuously increases in the style until day +7 . According to our macro. scopic observations, exudates rarely appeared on the stigma of $L$. X 'Enchantment' prior to or at anthesis and the top of stigma began to be covered by the exudates from day +1 to day +2 (unpublished data).

Based on our results and those of Ascher and Peloquin (1966), Ichimura and Yamamoto (1992), and Janson et al. (1994), pollination of Lilium spp. at post-bloom stages is more favorable for the pro- duction of viable seeds than pollination at anthesis.

\section{Self-incompatibility}

Our results show that on pollination made on day 0 , pollen germination and tube growth were retarded and that no viable seeds were obtained, compared with pollination made on day +3 (Fig. 3 , Table 2). These findings agree with those of Cheng and Mattson (1972), van Tuyl et al. (1982), and Li and Niimi (1995). Furthermore, in self-incompatible plants L. longiflorum 'Georgia' and 

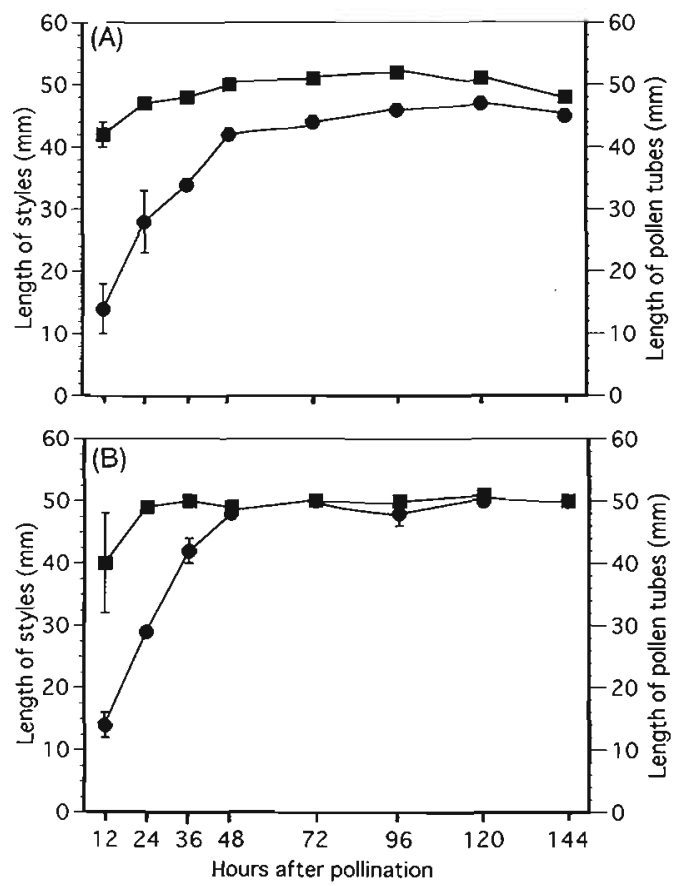

Fig. 4. Pollen tube growth in the styles of $L$. X 'Enchantment' flowers self-pollinated at anthesis (A) and on day +3 (B). ( $)$ : style length. (O): pollen tube length. The vertical bars indicate standard errors.
'Hinomoto' (Li and Niimi, 1995) and Petunia spp. (Ünal, 1986; Yasuda, 1929), the percentage of abnormal pollen tubes was higher in self-pollinated pistils than in cross-pollinated ones. Finally, generative cell division was delayed in pistils pollinated at anthesis compared with in those on day + 3. Unal (1986) observed that in the pollen tubes

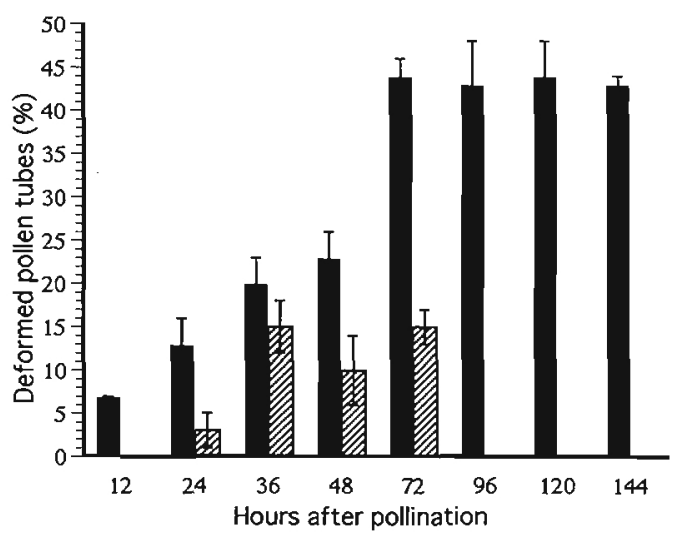

Fig. 6. Percentage of abnormal pollen tubes of $L$. X 'Enchantment observed at different times after being self-pollinated at anthesis $(\square)$ and on day $+3(\mathbb{Z})$. In the latter no tests were made on and after $96 \mathrm{hr}$. The vertical bars indicate standard errors.
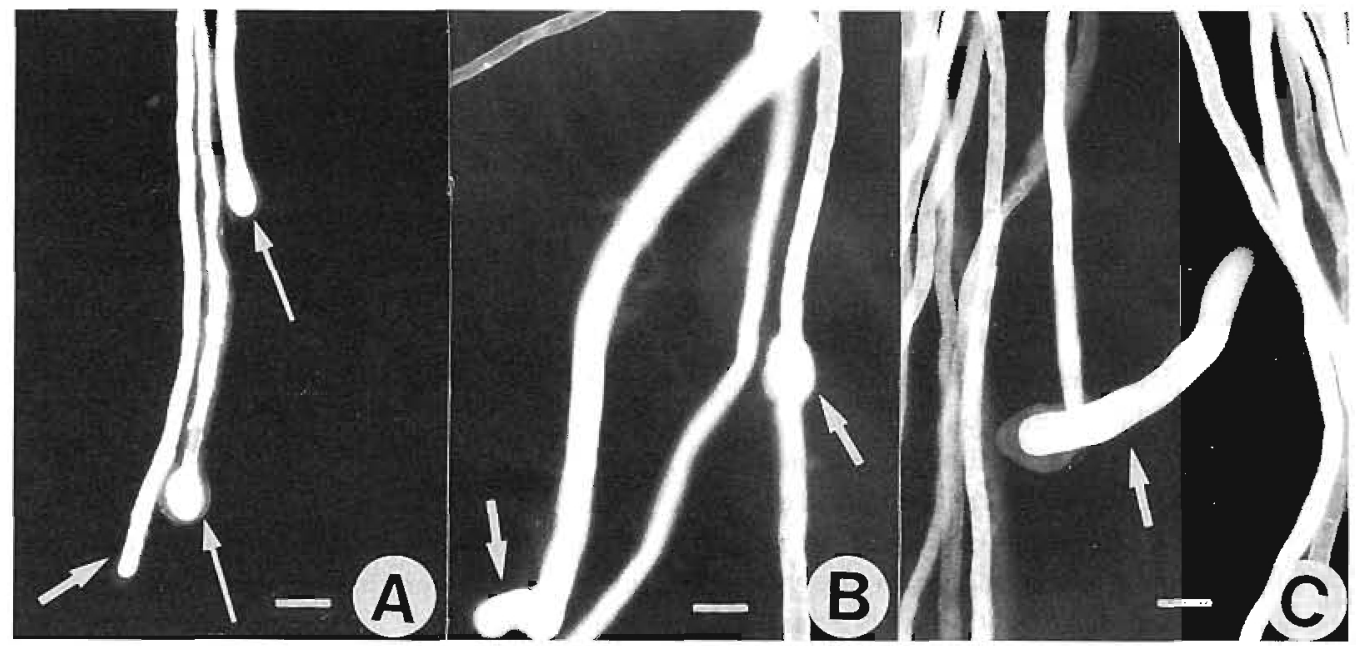

Fig. 5. Fluorescent photomicrographs of deformed pollen tubes in the styles of $L . \mathrm{X}$ 'Enchantment' flowers selfpollinated at anthesis. Observations were made at different time after pollination: (A) $24 \mathrm{hr}$, a normal pollen tube (left arrow) and two pollen tubes with a swollen tip; (B) $48 \mathrm{hr}$, pollen tubes with a protuberant tip (left arrow) or protuberance formed at a region away from a pollen tube tip (right arrow); and (C) $72 \mathrm{hr}$, a pollen tube with a fishhook-like tip. Bars represent $50 \mu \mathrm{m}$. 
Table 3. Relative pollen tube length (RPTL) and pollen tubes having one generative cell and one vegetative cell $(G+V)$ and 2 sperm cells and one vegetative cell $(2 S+V)$ in the styles of $L . \mathrm{X}$ 'Enchantment' flowers self-pollinated at anthesis and on day +3 .

\begin{tabular}{|c|c|c|c|c|c|c|c|c|}
\hline \multirow{3}{*}{$\begin{array}{l}\text { Hours after } \\
\text { pollination }\end{array}$} & \multicolumn{4}{|c|}{ Styles pollinated at anthesis } & \multicolumn{4}{|c|}{ Styles pollinated on day +3} \\
\hline & \multirow{2}{*}{$\begin{array}{l}\text { No. styles } \\
\text { observed }\end{array}$} & \multirow{2}{*}{$\begin{array}{l}\text { RPTL } \\
(\%)\end{array}$} & \multicolumn{2}{|c|}{ Pollen tubes with } & \multirow{2}{*}{$\begin{array}{l}\text { No. styles } \\
\text { observed }\end{array}$} & \multirow{2}{*}{$\begin{array}{l}\text { RPTL } \\
(\%)\end{array}$} & \multicolumn{2}{|c|}{ Pollen tubes with } \\
\hline & & & $\begin{array}{c}G+V \\
(\%)\end{array}$ & $\begin{array}{c}2 S+V \\
(\%)\end{array}$ & & & $\begin{array}{c}G+V \\
(\%)\end{array}$ & $\begin{array}{c}2 S+V \\
(\%)\end{array}$ \\
\hline 12 & 3 & $34 \pm 9$ & $93 \pm 5$ & $7 \pm 5$ & 3 & $36 \pm 5$ & 100 & 0 \\
\hline 24 & 7 & $59 \pm 1$ & $94 \pm 3$ & $6 \pm 3$ & 6 & $59 \pm 3$ & $78 \pm 10$ & $22 \pm 10$ \\
\hline 36 & 3 & $70 \pm 3$ & $90 \pm 8$ & $10 \pm 8$ & 3 & $82 \pm 4$ & 0 & 100 \\
\hline 48 & 7 & $84 \pm 2$ & $23 \pm 13$ & $77 \pm 13$ & 4 & $98 \pm 1$ & 0 & 100 \\
\hline 72 & 7 & $86 \pm 3$ & $13 \pm 8$ & $87 \pm 8$ & 5 & $98 \pm 1$ & 0 & 100 \\
\hline 96 & 5 & $88 \pm 2$ & $14 \pm 5$ & $86 \pm 6$ & 5 & $96 \pm 2$ & * & $*$ \\
\hline 120 & 7 & $92 \pm 1$ & $7 \pm 4$ & $93 \pm 4$ & 5 & $99 \pm 1$ & $*$ & $*$ \\
\hline 144 & 5 & $92 \pm 2$ & $6 \pm 4$ & $94 \pm 4$ & 7 & 100 & $*$ & $*$ \\
\hline
\end{tabular}

RPTL : (pollen-tube length/entire style-length) $\times 100$.

* : no tests were made.

of $P$. hybrida, mitosis occurred in incompatible tubes later than in compatible ones. Our observations give no clear evidence that some relation. ships exist between the delay of generative cell division in the pollen tubes and the self-incompatibility reaction. Lafleur and Mascarenhas (1978) showed that the RNA synthesis inhibitor, actinomycin $D$, prevents the division of generative cells in the Tradescantia pollen tubes. Therefore, in the pistils of $L$. X 'Enchantment' pollinated at anthesis, RNA and/or protein synthesis which are required for generative cell division may not progress smoothly.

We conclude from these findings that $L . X$ 'Enchantment' is a weakly self-incompatible cultivar.

\section{Seed viability}

Differences in mature seeds among those from selfed and crossed flowers at different stages were quite evident. Seeds from pistils which had been self-pollinated on day -2 or cross-pollinated on day 0 had the highest percent viability. The differences in seed viability among those pistils pollinated at different floral stages may be partly attrib. utable to the selection of pollen tubes. Mulcahy and Mulcahy (1975) mentioned statistically significant differences in germination time and seedling weight when pollination was made either on the tip or the basal portion of the stigmatic surface in Dianthus chinensis, and they suggested that the quality of the $F_{1}$ generation can be modified by competition among pollen tubes. We postulated that when self- and cross-pollination are made a few days after anthesis or under conditions favorable for tube growth, pollen tubes bearing undesirable characteristics succeed in fertilizing the egg because competition among pollen tubes is relatively weak. Consequently, some ovules filled slightly were weak and rarely germinated. Further studies are needed to fully support our postula. tion.

\section{Literature cited}

Ascher, P. D. and S. J. Peloquin. 1966. Effect of floral aging on the growth of compatible and incompatible pollen tubes in Lilium longiflorum. Amer. J. Bot. $53: 99-102$.

Cheng, I. H. and R. H. Mattson. 1972. Effect of in trastylar pollination methods on seed set of Lilium $\times$ 'Mid-Century' hybrid lilies. J. Amer. Soc. Hort. Sci. $97: 591-592$.

Ichimura, K. and Y. Yamamoto. 1992. Changes in the amount and composition of style canal exudate after self- or cross-pollination in self-incompatible Lilium longiflontm Thunb. J. Japan. Soc. Hort. Sci. $61: 609-617$.

Janson, J., M. C. Reinders, A. G. M. Valkering, J. M. Van Tuyl and C. J. Keijzer. 1994. Pistil exudate production and pollen tube growth in Lilium longiflorum Thunb. Ann. Bot. 73: 437-446.

Kho, Y. O. and J. Baër. 1968. Observing pollen tubes by means of fluorescence. Euphytica 17 : 298-302.

Lafleur, G. A. and J. P. Mascarenhas. 1978. The de- 
pendence of generative cell division in Tradescantia pollen tubes on protein and RNA synthesis. Plant Sci. Lett. 12 : 251-255.

Leopold, A. C. and P. E. Kriedemann. 1975. Plant growth and development. 2nd edition. p. 312. McGrow-Hill.

Li, T. H. and Y. Niimi. 1995. A comparison of seed sets in self-, intraspecific pollination of Lilium species by stigmatic and cut-style pollination methods. J. Japan. Soc. Hort. Sci. 64 : 149-159. (In Japanese with English summary).

Mulcahy, D. L. and G. B. Mulcahy. 1975. The influence of gametophytic composition on sporophytic quality in Dianthus chinensis. Theor. Appl. Genet. 46 : $277-280$.

Niimi, Y. 1991. An attempt at improving a technique of observing pollen tubes in the style of Lilium spp. Jpn. J. Palynol. 37 : 169-172. (In Japanese).

Shimizu, M. The Lily of Japan. 1971. pp. 285-286. Seibundo Shinkou-sha, Tokyo. (In Japanese).
Straathof, Th. P., J. Jansen and H. J. M. Loffler. 1993. Determination of resistance to Fusarium oxysporum in Lilium. Phytopatho. $83: 568-572$.

Takeoka, Y. and T. Wada. 1985. Observation by scanning electron microscopy. p. 24-41. In: Hojo, Y. and J. Ishizuka (eds). Experiments in crop physiology. Nogyo Gijutsu Kyokai, Tokyo. (In Japanese)

Ünal, M. 1986. A comparative cytological study on compatible and incompatible pollen tubes of Petunia hybrida. Istanbul Üniv. Fen Fak. Mec. Seri B. $51: 1-12$.

Van Tuyl, J. M., M. Clara Marcucci and T. Visser. 1982. Pollen and pollination experiments. VII. The effect of pollen treatment and application method on incompatibility and incongruity in Lilium. Euphytica 31 : 613-619.

Yasuda, S. 1929. Physiological researches on the fertility in Petunia violacea. VI. Growth of the pollen tubes in the style. Bot. Mag. XLIII. 156-169. (In Japanese with English summary)

\title{
アジアテイックハイブリッド‘エンチャントメント’の受容性と自家不和合性反応. 種子形成に及ぼす花齢の影響
}

\author{
新美芳二・李 同華・松尾勝仁 \\ 新潟大学農学部 950-21 新潟市五十嵐二の町 8050
}

摘要

本研究では，アジアテイックハイブリッド品種“エ ンチャントメントの受容性と自家不和合性反応を開 花 7 日前から開花 8 日後までの蕾または花に受粉して 調査した。

$$
\text { エンチャントメント’メイワュリ (L. maculatum) }
$$

の交雑受粉の結果, 開花 6 日前から開花 6 日後までの 雌ずいは健全な有胚種子を形成し，開花前日，開花 1 , 2，4 日後に受粉した場合，完熟種子数は開花当日に 受粉した場合より多く得られ，開花 2 日後の雌ずいは， さく果あたり 236 粒の種子を生じた.

‘ンンチントメント’の自家受粉では, 開花当日で は種子は形成されず，花粉管は花柱長の約 $85 \%$ しか 伸びなかった。 そして開花 3 日後に受粉した場合と比 較して，花粉管の先端が異常に肥大したり，奇形とな
った花粉管の割合が高く，また生殖核の分裂が遅れた 開花 3 日前から開花 6 日後までに受粉された雌ずいは， 開花当日を除いてすべての処理区でさく果を形成し， 開花 6 日後の雌ずいは 46 粒の完熟種子を, 他のもの は 10 数粒から 20 数粒の完熟種子を形成した。

自家受粉あるいは交雑受粉で得られた完熟種子を播 種してそれらの発芽力を調べたところ，その発芽開始 日および播種 45 日後の発芽率に違いがあった。交雑 受粉では開花当日に受粉した雌ずいから得られた種子 の発芽力がすぐれ，最終発芽率 $75 \%$ となった，一方， 自家受粉では開花 2 日前の受粉によって得られた種子 は $72 \%$ 発芽を示し，種子が最も多く得ら机た開花 6 日後の雌ずいの種子の発芽率は $44 \%$ であった。 